\title{
The dynamics of China-Ethiopia trade relations: economic capacity, balance of trade \& trade regimes
}

\author{
Manickam Venkataraman ${ }^{1 *}$ and Solomon M Gofie ${ }^{2}$
}

\author{
* Correspondence: \\ drvenkat65@gmail.com \\ ${ }^{1}$ Department of Defence and Strategic \\ Studies, University of Madras, Chepauk \\ Chennai - 600 005, Tamil Nadu, India \\ Full list of author information is \\ available at the end of the article
}

\begin{abstract}
China's trade with Ethiopia currently at 1.3 billion USD annually is expected to rise to US\$3 billion by 2015. This not only informs the level of bilateral trade ties that Ethiopia has had with China as compared to any other country in the region but also signifies the highest and the closest level of bilateral relations that Ethiopia has built upwith China over the past decade since the new government under Ethiopian People's Revolutionary Democratic Front (EPRDF) took over power in 1991. There have been extensive debates on China's role in Africa - whether it could be viewed as a constructive partner or otherwise. This essay puts forward the argument that while trade ties as one important channel of bilateral relations that China has embarked with the outside world and particularly with Africa is uneven and lop-sided. This is true of the Ethiopian context as well particularly when we look at the economic capacity, balance of trade and at the two countries relations with international trade regimes. While China is a full member of WTO for over a decade Ethiopia on the other hand has been aspiring to become a member for some time now and hence one of the important aspect of Ethio-China trade relations is the heavy reliance on bilateral/international trade regimes. Therefore, this research is aimed at unraveling the dynamics in Sino-Ethiopia trade relations with emphasis on the economic capacity of the two countries, balance of trade and explore whether Ethiopia's attempts to join WTO would lead to a more predictable trade relations between the two countries. In this attempt the research would largely rely on the analysis of relevant archival resources and literatures directly relating to the themes in this paper.
\end{abstract}

Keywords: Economic capacity; Bilateral trade; Trade imbalance; WTO

\section{Introduction}

A cursory glance at the manner in which China-Ethiopia political and economic relations has gained pace over the past two decades gives an impression that the momentum will only continue. Today there are many who argue that owing to the ideological/political compatibility between the incumbent governments in power that has for both domestic and international reasons pushed the various economic opportunities and challenges that the relations brought about to the backburner. Domestically, the tremendous economic development that China has been able to achieve over a short period lifting it to the level of second largest economic power has lent itself a model country for other African countries, notably Ethiopia. And externally China's five principles of peaceful co-existence or Panchsheel ${ }^{1}$ have come as a blessing in disguise for Ethiopia to fulfill its political and economic aspirations without hindrance as compared to that of its Western partners who

(c) 2015 Venkataraman and Gofie; licensee Springer. This is an Open Access article distributed under the terms of the Creative Commons Attribution License (http://creativecommons.org/licenses/by/4.0), which permits unrestricted use, distribution, and reproduction in any medium, provided the original work is properly credited. 
have been for long raking up issues that are considered detrimental to its political and economic interests.

However, the major argument of this paper is that challenges to bilateral trade relations have emanated in terms of the actual economic capacities of the two countries, the balance of trade, and the countries relations with international trade regimes. This is amply clear when one takes trade as an element of economic relations which, as will be shown below, is arguably lop-sided (Table 1 below highlights the differing capacity of trade among select African countries as a comparison with China), which is already a member of the World Trade Organization (WTO). On the other hand Ethiopia is only an aspirant for membership in WTO and hence stands to non-reciprocal trade relationships thereby leveraging bilateral agreements and understandings than subscribing to rules and trade regimes of international standing. This non-subscription to rules and trade regimes has contributed to the current imbalance in trade between the two countries. This article is an attempt to bring out the nittygritty of China - Ethiopia bilateral trade ties with reference to the economic capacity of the two countries, the challenges of trade balance, and applicable trade regimes/rules and regulations that could not only have potentially broader implications on relationships but also help to explain the nature of the relationships. By focusing on the dynamic nature of trade relations between Ethiopia and China, this study aims to contribute to the debate on the extent to which the on-going trade relations will be predictable enough for mutual benefits of the two countries, with in the broader context of China - Africa relations, and South - South relations.

\section{Perspectives on inter-state relations with focus on China-Ethiopia trade}

The enormous growth in bilateral trade between China and Ethiopia has raised several issues. China as the world's second largest economy with manufacturing industrial sector as its economic basis is far advanced than that of Ethiopia, whose economy is mostly concentrated on agricultural products. Even then, their bilateral trade has been on the upswing where China has been exporting low cost manufactured consumer products in return for access to Ethiopia's relatively large market and resources within the Horn of African region. A significant quantity of manufactured goods and machineries and transport equipment's are utilized by much of the Chinese firms in Ethiopia for the various infrastructural projects (Marcy-Francoise 2011:16). In contexts where there is asymmetry

Table 1 Differing capacities of trade by selected countries

\begin{tabular}{|c|c|c|c|c|}
\hline No & Countries & $\begin{array}{l}\text { Exports per } \\
\text { capita (USD) }\end{array}$ & $\begin{array}{l}\text { Export } \\
\text { volume }\end{array}$ & $\begin{array}{l}\text { Export of goods } \\
\& \text { services } \\
\text { (\% of GDP) }\end{array}$ \\
\hline 1 & Ethiopia & 24 & 2,003 & $11.5 \%$ \\
\hline 2 & Kenya & 125 & 4,555 & $23.5 \%$ \\
\hline 3 & Uganda & 98 & 3,388 & $23.6 \%$ \\
\hline 4 & Tanzania & 78 & 3,216 & $20.3 \%$ \\
\hline 5 & Ghana & 276 & 6,551 & $48.7 \%$ \\
\hline 6 & Nigeria & 423 & 66,100 & $34.2 \%$ \\
\hline 7 & South Africa & 1,483 & 73,100 & $26.7 \%$ \\
\hline 8 & Vietnam & 733 & 65,389 & $62.9 \%$ \\
\hline 9 & India & 124 & 145,800 & $11.6 \%$ \\
\hline 10 & China & 888 & $1,203,000$ & $24.1 \%$ \\
\hline
\end{tabular}

Source: Adopted from 'Economic Outlook-Sub-Saharan Africa 2010, IMF 2010 Country Reports'. 
in trade relations challenges in terms of the extent of trade reciprocities, trade imbalances, economic benefits, are inevitable. Problems of such nature are usually overcome through appropriate institutional mechanisms such as the WTO in order that it becomes obligatory for signatories to agree to abide by the institutional rules and regulations that have been put in place so that economic interactions can take place within an agreed framework effectively, and at the same allowing transparency and predictability in the relationships. In other words, the WTO agreements especially those involving reduction in tariff barriers have contributed towards the creation of a framework for an open trading system worldwide. Essentially therefore, it is not only the issue of asymmetric ties but also the potentiality of appropriate trade regimes that will be applicable in contexts where one trading partner, in view of its larger economic standing may be perceived in due course of time of benefiting more from the transactions. Although bilateral trade agreements provide scope for mutual observance of the same, there is little or no information on whether they are strictly adhered to. Such bilateral and multilateral agreements have been embarked upon by many countries including that of Ethiopia by undertaking several economic reforms aimed at overcoming economic crisis that have plagued them for many years $^{2}$. According to Kherallah et al. (cited in Mercy Mpinganjira 2012, p. 167) many subSaharan African countries experienced persistent deterioration of balance of payment accounts in view of the prolonged economic crisis caused by continuous decline in industrial production and commodity prices as well as stagnating agricultural sectors, the main stay of most of the economies. Hence many governments took measures that were not conducive enough to rectify the problems but only aggravated it. The level of seriousness with which countries attempt to realize their national economic objectives and goals is a matter of debate in view of the overlapping of political and economic spheres and thereby having implications upon their trade relationships. To a large extent this is true as can be witnessed from China's policy of non-interference in internal affairs as well as from the manner in which several projects are allotted to contractors through what most observers consider a less than transparent processes.

China's engagement with Africa and particularly with Ethiopia could best be understood under the rubric of the above framework (Jian Ye Wang 2007). The question of how and why incumbent regimes in Africa have viewed China to be their reliable development partner as against the West, which imposes political and economic conditionalities is crucial for understanding the context in which the trade relations under discussion is taking place. There is a perception that African countries in general have gone along to side with China since such conditionalities are absent and hence compatible with their larger political interests. In the case of Ethiopia, there were times where pressures from the West aimed at political and economic reforms have been put on hold due to the close ties with China. For example, the national elections in Ethiopia in 2005 and 2010 have added fuel to further complicating Ethiopia's relations with the West because both elections saw drastic violation of election code of conduct leading to wide-spread violence and drawing international criticisms. However, this did not affect bilateral relations with China in view of the latter's non-interference policy. Besides, in the area of trade, China became the trading partner of Ethiopia and the "two way bilateral trade that stood at \$100 million in 2002 rose to $\$ 562$ million in 2006” (Seifudein 2013:130).

Essentially therefore the perspectives revolve around two opposing debates. The first is that of the protagonists who perceive China's strategy as one aimed at enlisting African 
countries political support in order to gain economic benefits for its own economic modernization (He Wenping 2007). The second is that of the proponents' who look at China's involvement as one of South - South Cooperation in which Africa stands to benefit by way of China's huge soft loans and aid without strings attached. The proponents strongly argue that China is helping African countries to build infrastructural facility that China has embarked on in many African countries including that of Ethiopia (Ofidile et al. 2009, p.90; Gadzala and hanusch 2010). Remarkable to note in this regard is the construction of the African Union Headquarters in Addis Ababa, Ethiopia's capital, with Chinese help. Invariably, such reliance on China as an alternative partner has produced negative expectations from various quarters in terms of undermining the political reforms towards democracy initiated by African governments ${ }^{4}$.

Regardless however, China has become the alternative destination of much of African export products and relatively cheap manufacturing and industrial products for import, which has in turn provided a good amount of loans at low interest rates as well as invested in many infrastructural projects such as road construction, dams, railways and stadiums. This provides the perspective as well as the framework for analysis of the dynamics of China- Ethiopia trade relations in this article.

\section{Background on Ethio-China relations}

What is new in China-Africa relations (China and Ethiopia including) is the intensity with which the political and economic relations have developed particularly during the postcold war era that has captured the attention of many scholars (Y.S Cheng and Huang Shi 2009). However, their relations have evolved over along period and could be traced back to centuries when Chinese officials were sent to distant lands in search of what Gao (1984:241) points out as for alliance formation in order to counter the powerful Hun invasion from the North of China. Economic and trade ties have also been ongoing during these times when Chinese maritime traders had trade dealings with inhabitants of the coastal area along the Indian Ocean, and the Gulf of Aden and Persia and wherever merchants from different directions met (Filesi 1972: 1-10). Although opinions differ on the exact period of origin of Chinese contacts with Africa, what matters for the purpose of this article is the "ancientness" of China's political and economic relations with Africa and the dynamism with which it has proceeded in pace in the aftermath of the proclamation of People's Republic of China in October 1949. In fact, the emergence of China under a communist regime in international politics; the international political atmosphere at that point of time with U.S and Soviet Union breaking apart from one of World War II allies to one of post war enemies; the U.S. loss of China to the Soviet Union and China's siding with the Soviet camp against the U.S.; and later the breakup of SinoSoviet friendship in the late 1950s and 1960s - all of these have had a significant bearing on China's outlook of the World and Africa and Africa's outlook of China too.

China's identification of itself with that of the Third World and Africa and sharing a strong sense of ideological affinity besides its foreign policy principles based on noninterference can be singled out as factors that have bound them together to the extent of what is being debated today. This can be seen from the often reiterated statement that China and Africa share common developmental goals and converging interests with a win-win situation in all major forums and declarations (The Declaration on the third FOCAC 2006). The strength of Marxism-Leninism as a form of ideology emphasizing 
economic equality has had a profound impact on African leaders who were then waging their struggle for independence against colonial rule. It came at a time when African leaders were caught in a post-Colonial dilemma whether to embrace capitalism or any other form of system as a means of development. Arguably, the ideas that MarxismLeninism provided were strong enough to catch the attention of African leaders as the best way of governance. And obviously, the struggle for independence of these countries therefore turned to one of struggle between the West and the East to turn them on to their respective ideological camps, which very sadly continued even after these countries attained independence from their colonial masters. As a result, some of them indeed embraced this ideology while some others were brought under the Western camp. There is a strong indication that this ideological affinity can be seen in many of today's African countries, which follow more or less the same ideological lines of China including Ethiopia.

Of particular to note was the aspiration to expand relations with African countries which according to Larkin (1971:5-8; China's Africa Policy) was unquestionable. One can agree to this view as witnessed by the April 1955 Bandung Conference in Indonesia where for the first time 29 countries from Afro-Asian nations were brought together under one platform to unveil a sense of "third world" togetherness and solidarity as against the bipolar divisions that defined world politics then. And it was during this time that the first diplomatic contact with Africa took place and during which the "five principles of peaceful coexistence' or what is called "Panchsheel" was accepted. Interestingly, the Panchsheel served as the cornerstone of China's foreign policy and have remained so until today.

As mentioned earlier, China entered the African scene in support of their cause of independence and thereby to identify with African countries cause as one of "Third World

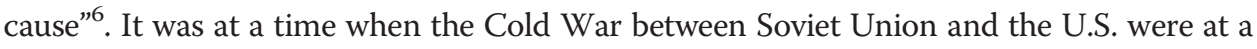
peak and both U.S and the Soviet Union were supporting African countries against each other. In fact, there were hardly any economic ties worth noting than the little political support that China offered to each other's cause at that time. However, a quick glance at the developments at the later years provides us the clue that China utilized economic incentives for consolidating political relationship, which was crucial for China to win over friendly relations at a point when the drift with the Soviet Union and other neighboring countries was widening. The period particularly between 1960 and 1965 was significant for China as it achieved great diplomatic successes by entering into diplomatic relations with 14 newly independent African countries such as Ghana, Mali, Congo and Uganda (Muekalia 2004, p.6).

China's relation with Ethiopia fits very much into this scenario in which one can identify three distinct phases: the Mao era between 1949 and late 1970s; the Deng Xiaoping era (1977-1990) and the post Cold War era. Notably, in the initial phase, China under ChouEn Lai visited Ethiopia in 1964 for the first time but wasn't reciprocated well by the ruling monarchical regime under Haile Selassie. This was largely in view of China's aspiration to introduce "Chinese revolutionary model" to African countries that were fighting against colonial rule as well as due to Ethiopia's close ties with the U.S.

In the later years, political conditions in Ethiopia were favorable for China to consolidate its relationship where the U.S.- China Détente led Ethiopia's Haile Sellassie to also follow suit. In fact within a year after the establishment of diplomatic relations with China in 1970 a bilateral agreement for economic and technological cooperation was entered into with Ethiopia in 1971. One can observe that more bilateral agreements were also signed 
during the period of the Derg regime (1974-1991) which had ideological similarities with China. Accordingly, economic and technological cooperation agreements were entered once again in 1988 and later in 2002. Several other agreements were also signed notably, the Sino-Ethiopian Trade Agreement of 1971 and 1976 and subsequently the SinoEthiopian Trade Protocol of 1984, 1986 and 1988 and the agreement for mutual promotion and protection of investment in 1988 (Geda 2008, p.4).

The above can also be seen in terms of China's realization of its 'long desired' economic goal of modernization that was brought about during the Deng Xiaoping era in late 1970s and in its aim to achieve political leverage within the international community, Africa attained top priority in due course of time. Interestingly, this trend in the Chinese posture is quite visible of late in view of two inter-related reasons. Firstly, in the aftermath of the adoption of the "modernization programme" in the late 1970s, China's focus of attention was more towards the West and particularly Japan and other European countries aimed at acquiring technology and hence Africa did not receive any significance. The leverage that could be gained from supporting anti-Soviet forces in Africa was perceived to be less significant given the emphasis on economic goals. But in the aftermath of the end of Cold War, not only China's economic ties with the West deteriorated, perhaps in view of the latter's criticisms of the Tiananmen Massacre, but also African countries themselves have started viewing China as a potential economic and political power aligned against the West particularly the U.S. These two developments have given a strong perception regarding the renewed emphasis on the part of China to look towards Africa as a new source of political and economic support to fulfill its political and economic ambitions ${ }^{7}$.

\section{Post 1991 developments in Sino-Ethiopian political and economic relations}

With the overthrow of the Derg regime and coming into power of Ethiopian People's Revolutionary Democracy Front (EPRDF) in 1991, Ethiopia's foreign policy turf underwent changes in tune with domestic and international changes. The transitional charter, notably, mentioned that the transitional government "will conduct its foreign relations on the basis of the principles of respect for the sovereignty and equality of states and nonintervention and non-interference in the internal affairs as well as the promotion of mutual interest" (Transitional Period Charter of Ethiopia Negarit Gazetta 1991, p.2). Subsequent constitutional principles have also reiterated, among others, the need for promoting development and operating within the broader globalized world by way of "creating a conducive environment for making use of available market and investment opportunity and getting technical assistance, loans and aid for the development and democratization endeavor of the country" (Ethiopian Foreign Policy Document 2002: pp. 2-15). The foreign policy document also mentions the need for realizing the twin objectives of bringing about democracy and development for which external economic support through economic diplomacy is needed (FDRE, Foreign Affairs and National Security Policy and Strategy 2002:23-24). The document further emphasized on securing China's Foreign Direct Investment and promote trade and investment in Ethiopia (Ibid: 151-152).

Ethiopia's post 1991 international foreign policy postures came at a time when Beijing was reeling under the Western criticisms of its human rights record such as those in reference to the 1989 Tiananmen Massacre. 
In tune with the above, the visit by Ethiopia's former Prime Minister Meles Zenawi to Beijing in 1995 and reciprocated by Chinese President Jiang Zemin later in 1996 concretized high level political relations and subsequently one can note series of high level visits to each other's national capitals. The launching of the Forum on China Africa Cooperation (FOCAC) in 2000 with subsequent Ministerial meetings provided the framework for China - Africa political and economic relations. It is through these forums that economic and political relations of China Ethiopia have been orchestrated (HarneitSievers et al. 2010).

\section{An overview of trade activities between China and Ethiopia}

Ethiopia, as a regional hub with several international organizations having headquarters in its capital, is a source of attraction for China more so with a population of about 90 million and a potential access for other regional markets such as the Common Market for Eastern and Southern Africa (COMESA) (Yejoo 2013: 183-184). With the introduction of liberalization policy in 1992 in Ethiopia, China poised to exploit this opportunity by investing in various economic sectors. Notable among others are road construction, electric power generation and telecommunication. Side by side, trade between the two countries has grown steadily through time. Moreover, Chinese firms have taken over several public producer firms with the "intention of exploiting the preferential treatments of Ethiopia in the industrial countries such as the African Growth and Opportunity Act (AGOA) in the USA" (Geda 2008:5). In all the above mentioned sectors, Chinese firms have won big projects like Tekeze Hydro Project and telecom sector by the Chinese company ZTE besides major highway construction. The Ethiopian telecommunication sector is dominated by the Chinese telecommunication technology. Alemayehu (Ibid: 7) is of the view that Chinese technology is not compatible with other technologies and hence China will have monopoly both in delivery of spare parts and after sale services in the years to come, providing scope for continued importation of Chinese goods as well. Thus, the growing and expanding scope of the relations with specific reference to trade is further reinvigorated through interactions between the two governments that have been intensified in recent times. Besides, a point worth noting is the Chinese industrial zone called Ethiopian Eastern Industrial Zone (EEIZ) some $37 \mathrm{~km}$ away from Addis Ababa in which more than 20 Chinese companies have invested in various projects such as textile and garment, shoe and leather products, food, electrical materials and steel manufacturing sectors (Geda 2009, p. 6).

In addition to the above, the two sides have been stepping up communication and coordination on the implementation of the eight new policy measures on assistance to Africa announced at the Fourth Ministerial Conference of FOCAC ${ }^{8}$. In January 2010 the Minister of Commerce of China, Chen Deming visited Ethiopia. The outcomes of the Beijing Summit of the Forum on China-Africa Cooperation (FOCAC) served as policy framework. On January 12 2010, Ethiopia and China signed agreement enabling to offer preferential market access to Ethiopia's export to China. Ethiopia's Trade and Industry Minister at that time, Mr.Girma Birru and Chinese Commerce Minister, Chen Deming signed the agreement. It was mentioned that the agreement covered about 95 per cent of Ethiopia's export to China, citing that trade exchange between the two countries has been growing by about 35 per cent annually on average. Chen Deming expressed his belief that 
the agreement will further enhance the existing trade and economic cooperation between the two countries. In July the same year, State Councilor of China Dai Bingguo visited Ethiopia and met with Ethiopian officials. The Chinese official described China-Ethiopia relationship as an excellent example of the friendly relations between China and African countries and mentioned that the two sides should seize the opportunities to advance cooperation and raise China-Ethiopia all-round partnership to a new level. Besides, in November 2011 another agreement for trade and economic cooperation were signed when the Chinese Vice Minister of Commerce Jiang Yaoping visited Ethiopia and met with Sufian Ahmed the Ethiopian Minister for Finance and Economic Development. According to the terms of the agreement China agreed to provide a loan of 100 million US Dollars and 90 vehicles including buses and automobiles ${ }^{9}$.

The above discussion about the general context in which Ethio-China bilateral relations takes place raises a number of issues having implications for the nature of trade relations between China and Ethiopia and for the applicability of international trade regimes in the future, beyond bilateral trade agreements. These are trade volumes or the size of export of the countries concerned, the balance of trade of the two countries, and thirdly the future role of international trade regimes with specific reference WTO rules, particularly to the issue of transparency.

\section{The volume of trade between China and Ethiopia}

According to information from ACCESS CAPITAL (2010) China has become one among the top destinations of Ethiopia's exports. In its 2010 report it observed that in terms of overall ranking, Switzerland topped the list having bought $\$ 224$ million of goods from Ethiopia and the amount of $\$ 215$ million were bought by China and the $\$ 196$ million bought by Germany (Chart 3). Access capital's report maintains that the emergence of China as one among the top destination of Ethiopian produces is part of the larger dynamics of "South-South" trade linkages by arguing that only four out of the top ten markets for Ethiopia's exports were located in the conventional 'West' (Switzerland, Germany, Netherlands, and U.S.) while the other six countries are in what might be termed as the 'South' (China, Somalia, Saudi Arabia, Sudan, UAE, South Africa). The report also makes the observation that countries with very low per capita income and highly volatile domestic political conditions such as the Sudan and Somalia for example have become among the larger markets for Ethiopia's exports compared to the volume of its exports to rich and politically considered democratic (Access Capital 2010).

In further describing Ethiopia's trade with China in some detail, an attempt is made here to examine the composition of exports to China based on available information. Accordingly, oilseeds, hides and skins and leather products, and mineral products were reported to be the three export commodities that went to China accounting for about 98 percent of the total export to China during the period 2002-2008 (Access Capital 2010, figure 4.2). Within this, oil seeds came on top where over 90 percent was accounted for by sesame export. Tanned/crust skins of goats and sheep constituted 55 percent of skin and hides products sent to china during the period 2006-2008. Titanium ores among the mineral products accounted for more than 90 percent of mineral export to China during the same period as reported in same source.

The major commodity categories imported from China includes, machinery and mechanical appliances; electrical equipment and parts, textiles, base metals, plastics, 
footwear, umbrellas and, vehicles, aircraft, vessels and transport equipment registering 200208 period average share of 35 percent, 25 percent, 10 percent, 6 percent, 5 percent and 3.5 percent, respectively. It was noted that the share of textile imports declined during the same period from about 41.3 percent of the total imports from China in 2002 to about 10 percent in 2008. The share of foot wear imports were also reported to have dropped from about 10 percent in 2002 to below 2 percent in 2008. It was mentioned that this was due to reduced domestic demand for Chinese textile and shoe products due to quality related problems. On the other hand, machinery and mechanical appliances imports were reported to have increased from about 18.7 percent in 2002 to about 55.2 percent in 2008. Plastic and rubber imports from China mainly pneumatic tires, rubber constituted 38 percent. Woven fabrics of synthetic yarn non-textured polyesters etc were among imports of larger volumes. Iron/ steel bars \& rods, hot rolled, twisted, rolling iron was cited to have been among the major components of metal imported from China. (A Survey of the Economic and Trade Relationships between China, India and Ethiopia (Ethiopian Economics Association 2009).

In general, Ethiopia's exports to China have been observed to have steadily increased over time although not diversified. There is also a perception that Ethiopia has been benefiting from the tariff and quota free preferential market access granted by China (Wudeneh 2010, p.2). China's grant of preferential treatment through duty and quota free preferential market access has progressively grown by evolving a policy to boost China Africa partnership (Eight Steps to Boost China -Africa Parternship 2007) by way of increasing 190 to 440 the number of export items China has been receiving. As mentioned, besides, China has also taken initiatives during the $3^{\text {rd }}$ CACOF Forum that allows Ethiopia to export over $95 \%$ of its products into Chinese market free of duty and quota limitations (Xinhua News Agency 2007).

Be that as it may, the bilateral trade relations have both challenges and opportunities. When examined from Ethiopian point of view domestic consumers and small scale business owners stood to benefit owing to China's cheap prices and low cost machineries and other related imported products (Geda 2008:11). Besides, there are significant amount of Chinese products that are imported through contraband trade by rent seeking China's business persons owing largely to the low import tax for items imported from China. This has also led to business practices such as illegally laminating on items imported from Europe the word "Made in China" in order to evade import taxes ${ }^{10}$. This raises the issue of the need for appropriate tariff arrangements that does not allow for illegality but retaining the essentials of market mechanisms.

Overall it is possible to say that regardless of the misgivings by scholars and observers concerning the relations between Ethiopia and China, their bilateral relations have picked momentum. The year 2010 marked the 40th anniversary of the establishment of diplomatic relations between the two countries, their partnership continued to deepen and their cooperation in various areas continues to be the basis for the ever expanding trade activates between the two countries. The understanding is that bilateral economic cooperation and trade grew even more rapidly since 2010.

In addition to the description of trade activities of Ethiopia with China, the following table comparatively shows the differing capacities of the two countries in terms of their trade volume at a global level.

A glance at the export per capita, the volume of export, and the GDP ratio of export of good and services of ten countries including Ethiopia and China in the above table 
clearly indicates the size and the varying capacities of export economy of the two coutnries.

\section{Balance of trade}

The other area that shows the nature of trade relations between China and Ethiopia is balance of trade in which the central points of concern is whether the country's enjoy positive trade balance or not. Ethiopia was reported to have recorded a trade deficit of 2366 Million USD in the fourth quarter of 2012. Balance of Trade for Ethiopia (see Figure 1) was reported to be -1556 Million from 2006 until 2012, -956.70 during the second quarter of 2007 and -2366.20 Million in the fourth quarter of 2012. From this and the chart indicated below Ethiopia's balance of trade has been in deficits due to its limited export largely owing to the limited nature of products exported to China. Moreover Ethiopia is a net importer of fuel and machineries. During this period about 18 percent of imports came from China as a major trading partner, followed with Saudi Arabia accounting for 13 percent of imports and 7 percent of exports of Ethiopia. The charts below clearly indicate the balanace of trade of both countries, showing that Ethiopia's trade balance is in the negatives while that of China is overwhelmingly on the positivie side ${ }^{11}$.

On the other hand China recorded a trade surplus of USD \$ 256.41 Million in December of 2013. Balance of Trade of China (Figure 2) as reported by the General Administration of Customs, averaged USD \$57.07 Million from 1983 until 2013, reaching USD \$404 Million in November 2008 and -USD \$319.71 Million in February of 2012. Information used indicates that since1995 China has been recording trade surpluses consistently. From 2004 to 2009 China's annual trade surplus was reported to have increased 10 times. China's biggest trade surpluses came from its trade with the United States, Netherlands, United Kingdom, Vietnam and Singapore, and some deficits are reported to have been recorded with Taiwan, South Korea, Australia, Germany, South Africa, Japan and Brazil ${ }^{12}$.

\section{The role of international trade regimes and implications for Ethio-China trade}

International trade is an important component of international relations. It is one of the tangible issue areas in interstate relationships. Multilateral and bilateral negotiations and agreements are central to international trade regimes. It is also important to mention the role of commercial laws and policies operating at the domestic level, regulating

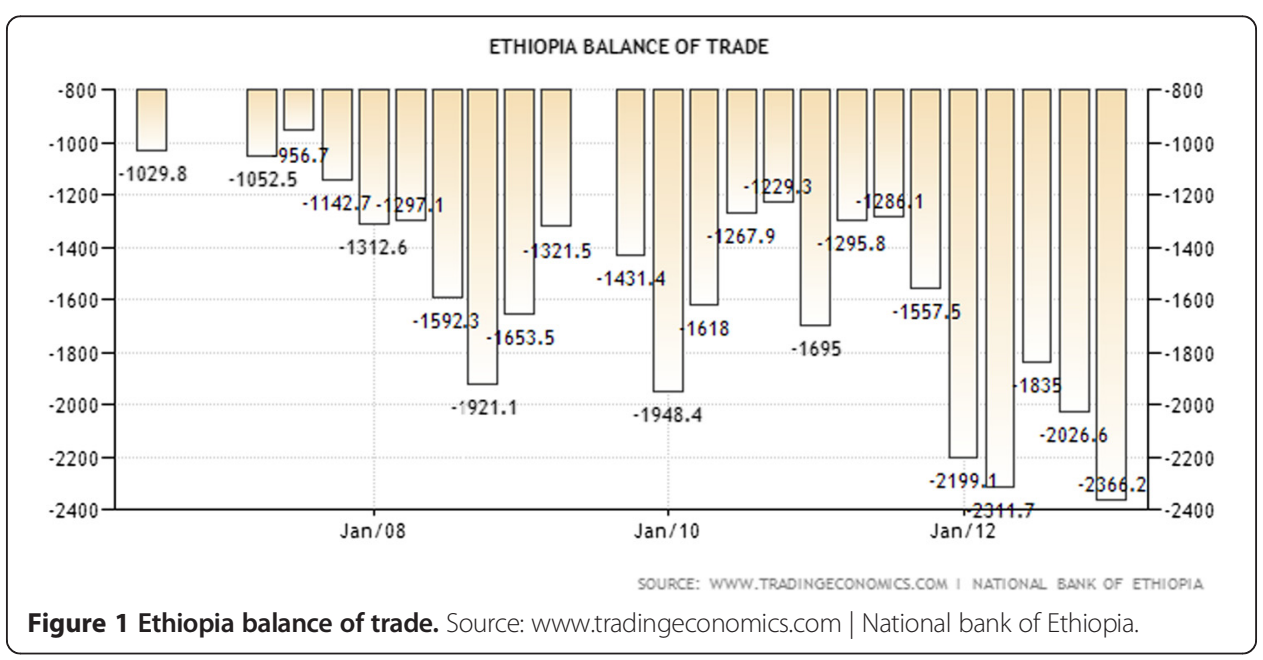




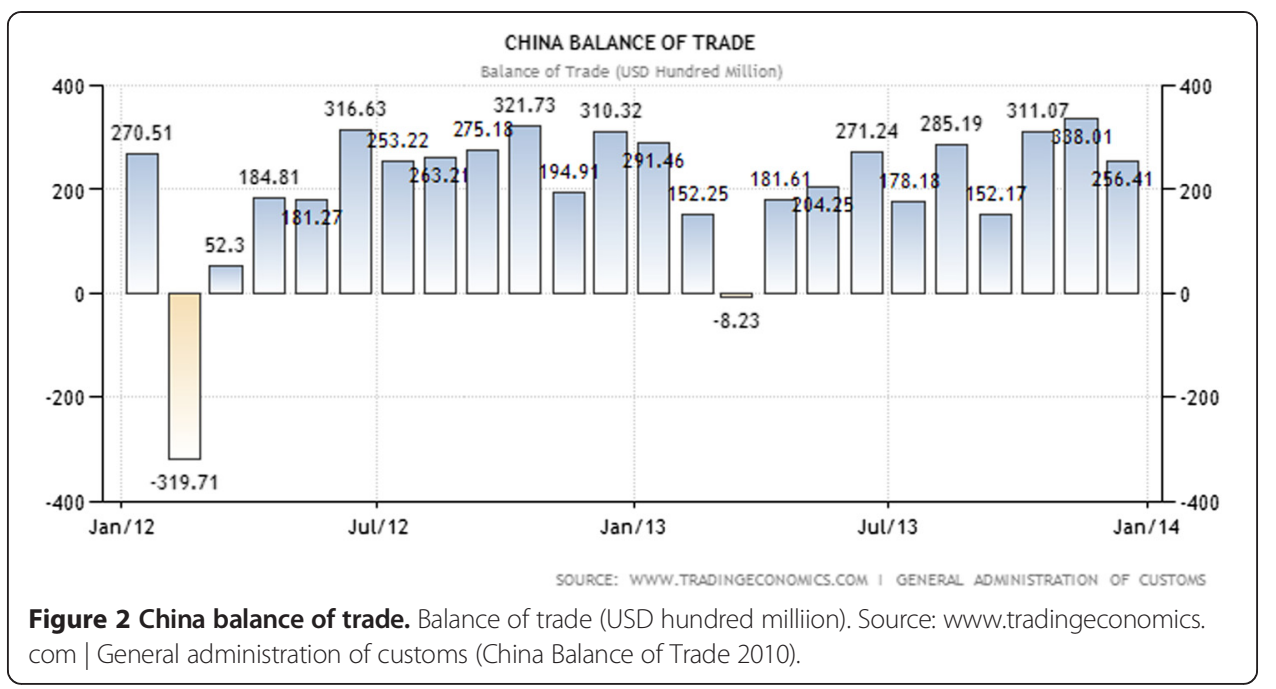

import and export activities besides bilateral or multi-lateral agreements having implications for the applicability international trade regimes. In this respect China is a member of World Trade Organization. A little more than a decade after being a member of the international body, it appears that it has come to terms with the rules of WTO. On the other hand Ethiopia is not a member of the WTO while it has shown an interest to join. This means that Ethio-China Trade is essentially based on bilateral trade agreements, and the fact that Ethiopia is not member would raise a number of issues.

It is important to note that the growing trade relations between the two countries take place within the larger framework of Chinese development assistance to Ethiopia. Trade between China and Ethiopia is largely based on mechanisms such as the Joint EthiopianChina commission (JECC), Sino-Ethiopian Agreement for Mutual Promotion and Protocol of Investment-1988, Sino-Ethiopia Agreement for trade, economic and technical cooperation-1996 and Forum for China Africa Cooperation (FOCAC) Sino-Africa at continental level, since recent times.

Against the background of pervasiveness of bilateral agreements Ethiopia's aspiration to become a member of WTO is part of this new dynamics. However, what has been questioned is its institutional capacity in the form of adjusting domestic laws and enacting, appropriate economic reforms in order to become an active member of the world organization. In this regard it was lately reported in a local news paper Addis Fortune, that after a period of reluctance, the government of Ethiopia submitted its application for membership in 2003. Since then the Government has been submitting documents dealing with Ethiopian trade regulations including a "memorandum on foreign trade regime" (Addis Fortune, December 8, 2013).

It is mentioned that in February 2012, Ethiopia submitted an offer on goods with a list of all tariff rates concerning imported goods. The understanding is that on the basis of the offers, WTO member states engage in negotiations with Ethiopian authorities bilaterally and as a whole. The information indicates that "trade negotiators from Canada, the European Union and the United States who have carried out readings of the offers and returned with questionnaires that totaled into the hundreds" (Ibid).

However, it is being repeatedly mentioned that Ethiopia's reluctance to open the telecom and the financial sector due to political reasons has repercussions on its 
aspiration to join the WTO as a multilateral trade forum. While opening up of telecom sector would invite voices of political dissent against the existing political system that is in place, opening the financial sector would risk the fragile economy to outside world. Interestingly enough Chinese Telecom companies have already gained huge concessions from the Ethiopian government as part of a range of bilateral agreements. This means that the representatives of countries which want to negotiate with Ethiopia at the WTO level on international trade rules work to persuade Ethiopia to reform domestic laws in order to make them compatible with the WTO rules of transparency and predictability.

As noted earlier, in the realm of China-Ethiopia trade relations, it is bilateral agreements that are at work. However, China's position on Ethiopia's attempt to join the WTO is not clear. In this regard, while WTO regime could also be unforgiving for China too, the situation of China is markedly different from that of Ethiopia. China has managed to join the WTO, and its perception towards the WTO is first one of challenges, then the understanding that becoming a member has finally paid off (Alden 2007). This is important in Ethio-China trade relations because, the WTO as an international trade organization has been working on the strengthening of the rules, and therefore one of the key concerns is transparency of trade practices of countries. In this regard, one of the texts agreed by member countries of the WTO recently relating to the principle of trade facilitation or transparency each to provide including online "a description of its importation, exportation and transit procedures, including appeal procedures that inform governments, traders and other interested parties of the practical steps needed to import and export, and for transit; the forms and documents required for importation into, exportation from, or transit through the territory of that member and contact information on enquiry points"13.

This makes transparency an issue in China-Ethiopia trade relations, arguably one of the most important in China-Ethiopia trade relations. Sooner or later, Ethiopia's joining the WTO would compel both countries to be making their bilateral trade dealings transparent and make the information pertaining to their trade relations available.

Related to the above is the requirement on the part of Ethiopia, in its attempt towards joining the WTO, in rewriting all national laws to comply with WTO rules and translating them all into one of the international working languages for the sake of transparency, as well as making it available to be viewed by anyone interested. In this respect while China has undergone this stage, this is going to be one of the major challenges for Ethiopia having implications for China- Ethiopia trade relations. In working towards this, it has been indicated that Ethiopia's Council of Ministers is currently reviewing the country's customs laws and is soon to refer it to Parliament for approval. Sources indicate that there have been several amendments designed to comply the country with WTO rules, according to fortune papers interview with government officials (Addis Fortune December 8, 2013).

Therefore given Ethiopia's non-accession status, international trade regimes have implications for China-Ethiopia trade. China being one of the dominant trading partner of the WTO and Ethiopia an aspiring least developing countries (LDC) it largely depends on bilateral agreements, sometimes enjoys quota- and duty free access to a number of major export markets including the USA (under the African Growth and Opportunities Act, AGOA), and the EU (under the Everything But Arms initiative, EBA), and with China. In the short term such preferential trade relations may be working, but in the long 
term this is subject to change. Ethiopia is believed to be enjoying access to markets which appears favorable than operating under WTO rules. It has been argued that the preferences which Ethiopia enjoys, with China, AGOA, EBA and others schemes can be withdrawn at will. However there is an argument that withdrawal from such schemes could damage the reputation of the withdrawing country. Therefore, becoming a member of WTO by countries such as Ethiopia could provide scope for the predictability of trade strategies of the country and also have strong implications for its transparency in its trade with China. The assumption here is the fact that if Ethiopia is admitted as a member of WTO like China it would lead to the expectation that the trade behaviors of countries will be more predictable and transparent. This is also important because the international trade regimes besides representing the interest of industrialized countries could also advance the interests of developing countries at a multilateral level, beyond the bilateral schemes. In the words of Bienen, (2010: 25) "if Ethiopia remained outside of the WTO it would be barred from entering into these negotiations and representing its own interests - while at the same time being affected by the negotiation outcomes".

Moreover, the issue of transparency is important not just for the WTO and the adherence to its rules by member countries but also for the private sectors and trading communities of both countries. It is expected that WTO would bring benefits for the Ethiopian private sector. It is argued that WTO accession or subscription to more transparent trade regimes beyond preferential treatment will change the rules of doing business in Ethiopia by strengthening the forces of the market. The argument is that competition will gradually increase, creating opportunities for the private sectors. According to the World Bank's Doing Business indicators, Ethiopia is believed to be not doing well as the role of private sector in international trade is limited (Ibid). More importantly the challenges of transparency and the availability of information do affect not only member states of multilateral and bilateral trade agreements, but also the domestic actors who in fact are the engine of international trade.

\section{Conclusions}

It has been noted that the common interests of African countries warm relations with China is "constantly" expanding, and the future of their economic and trade cooperation is bright. China-Africa economic exchanges will continue to expand within bilateral or multilateral frameworks, broaden the scope of cooperation and explore new methods of cooperation.

The existence of favorable Africa wide framework means that China-Ethio trade has been largely perceived as a show case of such relations with African countries. This is also important for the ever growing trade relations between the two countries and Ethiopia seem to be enjoying preferential trade relations. However, as noted above, the trade relations face challenges in terms of the existing differences in capacity of trade that Ethiopia in particular has to offer contributing to imbalance in trade and thereby questioning issues of predictability and transparency. In other words, unless and until their bilateral trade relations are on predictable and transparent path it would be difficult to continue to have such beneficial trade relations. In this regards, Ethiopia's non-membership in WTO would only help continue their relations but once Ethiopia is accepted to be a member then things would not remain the same.

From the point of view of Ethiopia its bilateral trade with China has often been viewed in the framework of China's Eight Point plan it pledged at the Fourth FOCAC Ministerial 
Conference. One of the major offers on the part of China was to further open its market to African countries. It claims to offer zero-tariff treatment to $95 \%$ of exports from the LDCs in Africa having diplomatic relations with China (China Ministry of Commerce February 15, 2011).

The predominant perception of China-Africa Economic relations in general and trade relations in particular has often been the presumption of complementarity. However, China as the second largest economy in the world is by far no match with that of Ethiopia. As has been noted the volume of export of trade of the countries is asymmetrically different. The difference in the economic capacity of the two countries is more pronounced in the balance of trade of the country's economies. The fact that China's trade balance is overwhelmingly positive and that of Ethiopia's is in the negatives is emblematic of explaining the differing capacity of the two countries. This in a way contributes to the perception that the situation is in favor of China.

Nevertheless, it appears that China being aware of the strategic importance of its relations with the Ethiopian government has created scope for all-round supportive relations between the two. This means that irrespective of the varying capacities of the economies of the two countries, they have been able to create the image of comrades in arms who are not harming each other. Trade therefore is seen as one of the broad packages of what the leadership in both countries portrays has been catering for mutual benefit of the two countries.

This has also created a situation whereby bilateral agreement and preferential relations have been the norm in Ethio-China trade relations. In this regard the role of international trade regime appears to be less significant. It is not clear how China that is now an important member of WTO and Ethiopia that is pondering to join will continue to be viewed by different actors such as domestic businesses, and especially by countries that are aiming to enter into a more serious trade negotiations following Ethiopia's bid to join the WTO. Beyond the highly varying capacity the issue of transparency in the trade relations between the two and especially in making trade information publicly available will be an important issue that is relevant for subnational actors in China and Ethiopia and for those who are members of the international trade regime already.

In conclusion, the dynamics of China- Ethiopia trade relations could better be understood when assessed on the basis of the economic capacity, trade balance and the impact of international trade regimes. In other words, China-Ethio trade relations do not take place in isolation and these needs to be understood in the context of wider dynamics. It is found to be important to reflect on the significance of themes in international trade in making sense of China-Ethiopia trade relations beyond popular perceptions. In this respect, the volume and balance of trade, and applicable trade agreements and regimes are found to be relevant in examining the dynamics of trade relations between the two countries. In particular, it will be interesting to see how Ethiopia's bid to join the WTO will likely to affect bilateral trade agreements between the two. Moreover the outcomes of negotiations including becoming a member of international trade organizations or regimes involve the issue of capacity of the economies and their experts'. In this regard too, whether Ethiopia may learn a lesson of how China has been able to garner the necessary capacity including the capacity of its trade negotiators will be a possible topic for future research. 


\section{Endnotes}

${ }^{1}$ The five principles of peaceful coexistence otherwise known as Panchsheelviz: 1) Oppose imperialism and colonialism 2) non-interference in each other's internal affairs 3) non-aggression 4) equality and mutual benefit and 5) peaceful co-existence was adopted in 1954 and was incorporated in the Sino-Indian Agreement on Trade and intercourse between India and the Tibet Region of China. The preamble of the Agreement contains the famous Panchsheel. Refer R.K. Jain, ed, China South Asian Relations, 1947-1980, (Jain 1981), p.61.

${ }^{2}$ For a good account on the interplay of political and economic challenges confronting African economies, see AlemayehuGeda and Addis Yimer, "Growth and Poverty Reduction in Africa: Political Economy Challenges" in Yaruingam and Kapoor 2013, pp. 106-125.

${ }^{3}$ See also the UN Commodity Trade Statistics Database (COMTRADE) (2010), http://www.comtrade.un.org?

${ }^{4}$ China's Increasing Interest in Africa: Benign but Hardly Altruistic, http://www. brookings.edu/blogs/up-front/posts/2013/04/05-china-africa-sun accessed 8th September 2014.

${ }^{5}$ As per the "Three World's Theory" put forward by Chairman Mao-tse Tung, countries of Asia, Africa and Latin America were linked to form the third world while US and the former Soviet Union as forming the first and those others in Europe, Canada and Japan as part of the second world respectively.

${ }^{6}$ For a comprehensive discussion on this see, Larry Hanauer, Lyle J. Morris, Chinese Engagement in Africa: Drivers, Reactions and Implications for U.S Policy, RAND, 2014.

${ }^{7}$ For an excellent analysis on China's emergence in the new world order see Gerald Chan, The Rise of Multipolarity, the Reshaping of Order: China in a Brave New World?, International Journal of China Studies, vol.4, no.1, April 2013, pp. 1-16.

${ }^{8}$ Forum on China - Africa Cooperation, www.focac.org/eng/dsjbzjhy/hywj/t626387. htm accessed 8th February 2014.

${ }^{9}$ Ethiopia, China sign agreement on trade, economic cooperation, Xinhua News Agency, http://english.peopledaily.com.cn/90883/7647622.html accessed 8th October 2014.

${ }^{10}$ http://www.zegabi.com/articles/6148 accessed 10th October 2014; see also Dr. Lishan Adam, "What is happening in ICT in Ethiopia", http://www.researchictafrica. net/publications/Evidence_for_ICT_Policy_Action/Policy_Paper_3_-_Understanding_what_ is_happening_in_ICT_in_Ethiopia.pdf.

${ }^{11}$ EEthiopia Balance of Trade' (2010).

${ }^{12}$ Ibid.

${ }^{13}$ See Agreement on Trade Facilitation, Bali, 7 December 2013, p.2.

Competing interests

Dr. M. Venkataraman His research interests are as follows: Political Economy, Foreign Policy, Security and Strategic Studies.

Dr. Solomon Mebrie Foreign Policy, Human Rights, and Development Discourse.

Authors' contributions

VS carried out the framework for the article and exchanged notes and worked on the initial drafts which were then read through by both authors. Both authors read and approved the final manuscript.

Author details

1Department of Defence and Strategic Studies, University of Madras, Chepauk Chennai - 600 005, Tamil Nadu, India.

²Department of Political Science and International Relations, Addis Ababa University, Addis Ababa, Ethiopia. 
Received: 7 November 2014 Accepted: 10 November 2014

Published online: 05 February 2015

\section{References}

Access Capital. 2010. Ethiopia's Export Performance". http://www.accesscapitalsc.com/.

Addis fortune. 2014. FACES OF Negotiation: Ethiopia enters crucial phase of WTO accession bid". addisfortune.net, accessed January 302014.

Alden, Chris. 2007. China in Africa. London and New: York. Independent News and Media Plc, Addis Ababa.

Bahtawi. 2014. ZTE failed to pay 1 billion birr tax. http://mereja.com/forum/viewtopic.php?f $=2 \& t=84222$ accessed 10th October 2014.

China Balance of Trade. 2010. http://www.tradingeconomics.com/ethiopia/balance-of-trade, accessed Feb. 2010.

China Ministry of Commerce February 15. 2011. China-Africa Economic and Trade Cooperation". http://english.mofcom. gov.cn/article/zt_minister/lanmua/201102/20110207420897, accessed Jan 2014: Information Office of the State Council. http://english.mofcom.gov.cn/article/zt_minister/lanmua/201102/20110207420897, accessed Jan 2014.

IMF Country Report, Economic Outlook-Sub-Saharan Africa. 2010. Washington D.C. https://www.imf.org/external/pubs/ $\mathrm{ft} / \mathrm{reo} / 2010 / \mathrm{afr} / \mathrm{eng} / \mathrm{sreo1010.htm} \mathrm{accessed} \mathrm{11th} \mathrm{December} 2014$.

Ethiopia Balance of Trade. 2010. http://www.tradingeconomics.com/ethiopia/balance-of-trade, accessed Feb. 2010.

Ethiopian Economics Association. 2009. A Survey of the Economic and Trade Relationships between China, India and Ethiopia. Addis Ababa: Ethiopia. http://www.eeaecon.org/.

FDRE. 2002. Foreign Affairs and National Security Policy and Strategy.

Filesi, Teobaldo. 1972. China and Africa in the Middle Ages. London: Frank Cass.

Gadzala, Aleksandra, and Marek Hanusch. 2010. African Perspectives on China and Africa: Gauging Popular Perceptoins and Their Economic and Political Determinants. U.S.A: Afro Barometer Working Paper 117. www.afrobarometer.org, accessed 8th September 2014.

Gao, Jinyuan. 1984. China and Africa: the development of relations over many centuries. African Affairs 83(331): 241-250.

Geda, Alemayehu. 2008. Scoping Study on the Chinese Relations with Sub-Saharan Africa: The Case of Ethiopia. Nairobi: African Economic Research Consortium.

Geda, Alemayehu. 2009. Impact of China - Africa Investment Relations: Case Study of Ethiopia. Nairobi: African Economic Research Consortium.

Harneit-Sievers, Axel, Stephen Marks, and Sanusha Naidu (eds.). 2010. Chinese and African Perspectives on China in Africa. Uganda: Fountain Publishers

He, Wenping. 2007. The balancing act of China's Africa policy. China Security 3(3): 23-40. World Security Institute. Jain, RK. 1981. China South Asian Relations, 1947-1980. New Delhi: Atlantic Highlands.

Larkin, BD. 1971. China and Africa, 1949-1970: The Foreign Policy of the People's Republic of China. Berkely: California University Press.

Marcy-Francoise, Renard. 2011. China's Trade and FDI in Africa. Tunisia: African Development Bank Group Working Series No 126.

Ministry of Foreign Affairs. 2002. Ethiopian Foreign Policy Document, 2-15. Addis Ababa.

Mpinganjira, Mercy. 2012. International Trade Promotion inSouthern Africa: Challenges and Lessons. http://dx.doi.org/10.5772/50096. accessed 8th April 2014.

Muekalia, Jardos Domingoes. 2004. Africa and China's strategic partnership. African Security Review 13(1): 5-11.

Ofidile, Uche, Aid Trade, and Human Rights: China's Africa Policy in Perspective. 2009. Journal of international commercial law and technology 4(2): 1-99. http://www.jiclt.com/index.php/jiclt/article/viewFile/73/72 accessed 8th September 2014.

Seifudein, Adem. 2013. Diplomacy and Economics of Sino-Optimism in Ethiopia. In Mazrui and Seifudein Adem, Afrasia: A Tale of Two Continents, ed. A Ali. Maryland: University Press of America.

Stahl, Anna Katharina. 2013. Fostering African Development, Governance and Security through Multilateral Cooperation between China and Western Donors: The Case of China - DAC Study Group. In China-Africa Relations: Governance, Peace and Security, ed. Berhe Mulugeta Gebrehiwot and Hongwa Liu. Addis Ababa: Institute of Peace and Security Studies.

The Declaration on the third FOCAC. 2006. Beijing: Xinhua News Agency. http://news.xinhuanet.com/english/2006-11/ 16/content 5336745.htm accessed 11th December 2014

Transitional Period Chart of Ethiopia. 1991. Negarit Gazetta. Addis Ababa, http://www.lo.org/dyn/natlex/docs/ ELECTRONIC/85164/95206/F462379375/ETH85164.pdf

UN Commodity Trade Statistics Database (COMTRADE). 2010. http://www.comtrade.un.org accessed on 14th January 2014. Wang, Jian-Ye. 2007. What Drives China's Growing Role in Africa? IMF Working: Paper.

Wudeneh, Zenebe. 2010. Africa may reap export harvest in China". Addis Ababa, http://www.addisfortune.com/Vol\% 2010\%20No\%20507\%20Archive/agenda.htm, accessed February 10, 2014.

Y.S Cheng, Joseph, and HG Shi. 2009. China's African policy in the post cold war era. Journal of Contemporary Asia. 39: 87-115.

Yaruingam, AS, and Rashmi Kapoor (eds.). 2013. Inside Africa: Contemporary Perspectives. Centre for African Studies: University of Delhi, Shipra Publications.

Yejoo, Kim. 2013. Chinese Investment and African Peace and Security: The Case of Ethiopia. In China - Africa Relations: Governance, Peace and Security, ed. Berhe Mulugeta Gebrehiwot and Hongwa Liu. Addis Ababa: Institute of Peace and Security Studies.

China's Africa Policy. People's Daily Online - http://english.people.com.cn/ accessed 12th February 2014.

Eight Steps to Boost China-Africa Partnership". 2007, Xinhua News Agency. http://news.xinhuanet.com/misc/2007-01/30/ content_5673868.htm, accessed February 2014.

Ethiopia, China sign preferential Trade Agreement". 2007, nazret.com/blog/index.php/.../ethiopia_china_sign_ preferential_trade_January 12 2010, accessed January 02, 2014

Ethiopia - China Sign Agreement on Trade and Economic Cooperation. 2007, http://news.xinhuanet.com/english2010/ china/2011-11/17/c_131251360.htm accessed 11th April 2014. 
Ethiopia, China sign Agreement on Trade, Economic Cooperation, Xinhua News Agency. http://english.peopledaily.com. cn/90883/7647622.html accessed 8th October 2014.

Forum on China - Africa Cooperation. 2014. www.focac.org/eng/dsjbzjhy/hywj/t626387.htm accessed 8th February 2014

Huawei to Recover Equipments seized by Ethiopian Customs. 2013, http://www.zegabi.com/articles/6148 accessed 10th October 2014.

Xinhua News Agency. 2007. http://www.focac.org/eng/ltda/dscbzjhy/DOC32009/t280369.htm.

\section{Submit your manuscript to a SpringerOpen ${ }^{\circ}$ journal and benefit from:}

- Convenient online submission

- Rigorous peer review

- Immediate publication on acceptance

- Open access: articles freely available online

- High visibility within the field

- Retaining the copyright to your article

Submit your next manuscript at $>$ springeropen.com 